\title{
Conformational study of lanthanide(III) complexes of $N$-(2-salicylaldiminatobenzyl)- 1-aza-18-crown- 6 by using X-ray and ab initio methods
}

\author{
Marina González-Lorenzo, Carlos Platas-Iglesias", Marta Mato-Iglesias, David Esteban-Gómez,

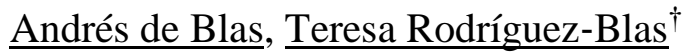

Departamento de Química Fundamental, Facultad de Ciencias, Universidade da Coruña, Campus da Zapateira s/n, 15071 A Coruña, Spain

Polyhedron, volume 27, issue 5, pages 1415-1422, 7 April 2008

Received 14 December 2007, accepted 11 January 2008, available online 21 February 2008

\section{How to cite:}

M. González-Lorenzo, C. Platas-Iglesias, M. Mato-Iglesias, D. Esteban-Gómez, A. de Blas, T. Rodríguez-Blas, Conformational study of lanthanide(III) complexes of N-(2-salicylaldiminatobenzyl)-1aza-18-crown-6 by using X-ray and ab initio methods, Polyhedron. 27 (2008) 1415-1422. https://doi.org/10.1016/j.poly.2008.01.004.

(C) 2008. This manuscript version is made available under the CC Attribution-NonCommercialNoDerivatives 4.0 International license: http://creativecommons.org/licenses/by-nc-nd/4.0.

\begin{abstract}
A structural study of lanthanide complexes with the deprotonated form of the monobracchial lariat ether $\mathrm{N}-2$ salicylaldiminatobenzyl-aza-18-crown-6 $\left(\mathbf{L}^{4}\right) \quad(\mathrm{Ln}=\mathrm{La}(\mathrm{III})-\mathrm{Tb}(\mathrm{III}))$ is presented. Attempts to isolate complexes of the heaviest members of the lanthanide series were unsuccessful. The $\mathrm{X}$-ray crystal structures of $\left[\mathrm{Pr}\left(\mathrm{L}^{4}\right)\left(\mathrm{H}_{2} \mathrm{O}\right)\right]\left(\mathrm{ClO}_{4}\right)_{2} \cdot \mathrm{H}_{2} \mathrm{O} \cdot \mathrm{C}_{3} \mathrm{H}_{8} \mathrm{O}$ and $\left[\mathrm{Sm}\left(\mathrm{L}^{4}\right)\left(\mathrm{H}_{2} \mathrm{O}\right)\right]\left(\mathrm{ClO}_{4}\right)_{2} \cdot \mathrm{C}_{3} \mathrm{H}_{8} \mathrm{O}$ show the metal ion being bound to the eight donor atoms of the ligand backbone. Coordination number nine is completed by the oxygen atom of an inner-sphere water molecule. Two different conformations of the crown moiety (labelled as $\mathbf{A}$ and $\mathbf{B}$ ) are observed in the solid state structure of the $\operatorname{Pr}(\mathrm{III})$ complex, while for the $\mathrm{Sm}$ (III) complex only conformation $\mathbf{A}$ is observed. The complexes were also characterized by means of theoretical calculations performed in vacuo at the $\mathrm{HF}$ level, by using the $3-21 \mathrm{G}^{*}$ basis set for the ligand atoms and a $46+4 \mathrm{f}^{n}$ effective core potential for lanthanides. The optimized geometries of the $\operatorname{Pr}(\mathrm{III})$ and $\operatorname{Sm}(\mathrm{III})$ complexes show an excellent agreement with the experimental structures obtained from X-ray diffraction studies. The calculated relative energies of the $\mathbf{A}$ and $\mathbf{B}$ conformations for the different $\left[\mathrm{Ln}\left(\mathrm{L}^{4}\right)\left(\mathrm{H}_{2} \mathrm{O}\right)\right]^{2+}$ complexes ( $\mathrm{Ln}=\mathrm{La}, \mathrm{Pr}, \mathrm{Sm}$, Ho or $\mathrm{Lu}$ ) indicate a progressive stabilization of the $\mathbf{A}$ conformation with respect to the $\mathbf{B}$ one upon decreasing the ionic radius of the $\mathrm{Ln}(\mathrm{III})$ ion. For the $\left[\mathrm{Ln}\left(\mathrm{L}^{4}\right)\left(\mathrm{H}_{2} \mathrm{O}\right)\right]^{2+}$ systems, most of the calculated bond distances between the metal ion and the coordinated donor atoms decrease along the lanthanide series, as usually observed for $\operatorname{Ln}(\mathrm{III})$ complexes. However, our ab initio calculations provide geometries in which the $\mathrm{Ln}-\mathrm{O}(5)$ bond distance $[\mathrm{O}(5)$ is an oxygen atom of the crown moiety] increases across the lanthanide series from Sm(III) to Lu(III).
\end{abstract}

Keywords: lanthanides; macrocyclic ligands; crown compounds; ab initio calculations

\footnotetext{
* carlos.platas.iglesias@udc.es

† teresa.rodriguez.blas@udc.es
} 


\section{Introduction}

Applications of trivalent lanthanide complexes as contrast agents for NMR imaging [1], catalysts for specific cleavage or RNA hydrolysis [2], stains for fluorescence imaging [3], responsive luminescent systems [4] or as active agents in cancer radiotherapy [5] have prompted considerable interest in lanthanide coordination chemistry [6]. The cyclic framework of crown ethers affords an interesting platform for the complexation of metal ions and, in particular, the hard acid character of the crown moiety makes crown ethers interesting potential ligands for the complexation of trivalent lanthanide ions [7]. Moreover, the relative facility with which crown ethers can be functionalised with pendant arm(s) containing additional donor atom(s) allows to enhance the cation binding ability and the selectivity of the parent crown ether [8,9]. In previous papers, we have described the coordinative ability towards lanthanide(III) ions of bi-armed crowns containing 2salicylaldiminato-benzyl pendants and derived from 4,13-diaza-18-crown-6 ( $\left.\mathbf{L}^{1}\right)$ [10], 1,10-diaza-15-crown-5 $\left(\mathbf{L}^{2}\right)$ [11] and 4,10-diaza-12-crown-4 ( $\left.\mathbf{L}^{3}\right)$ [12] (see Scheme 1).
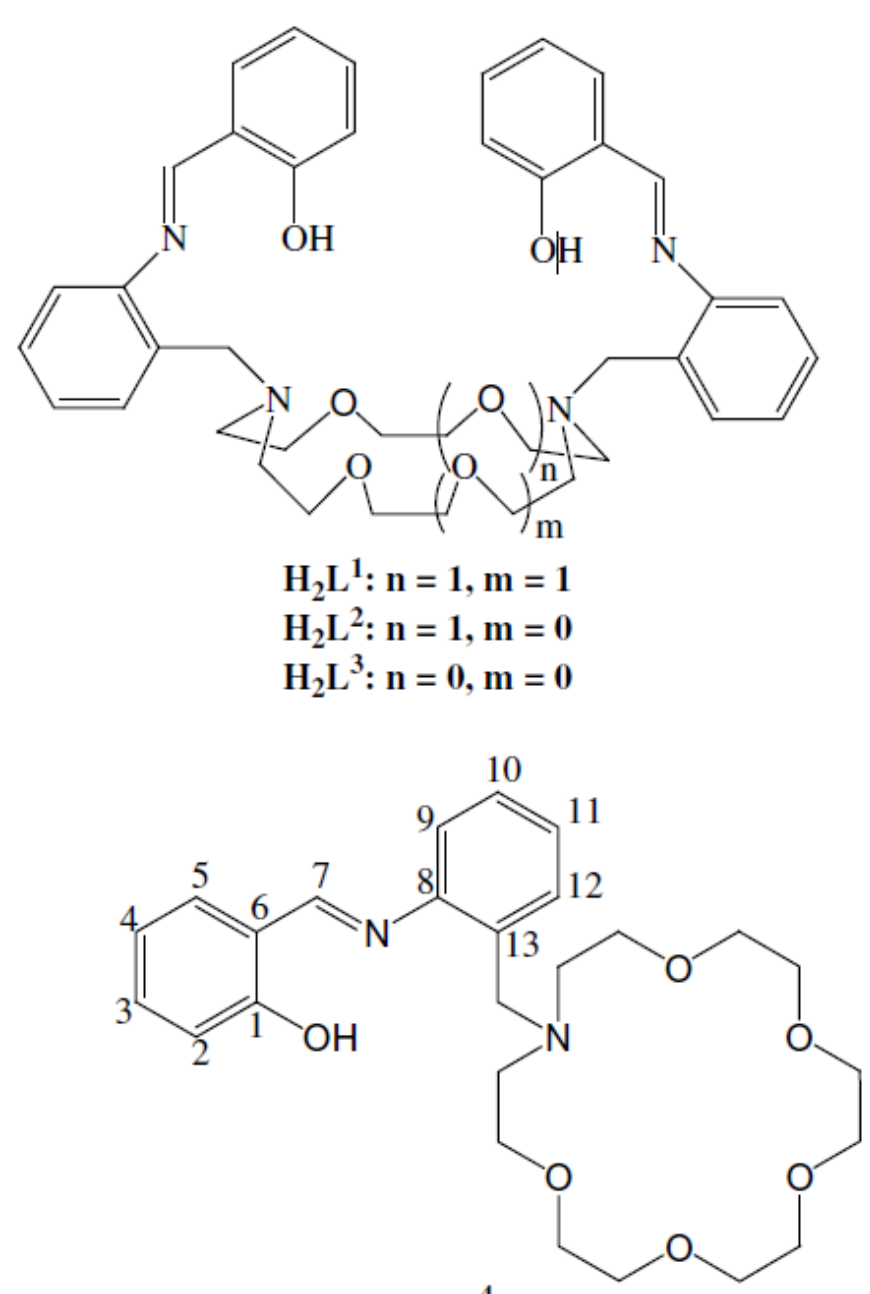

$\mathrm{HL}^{4}$

Scheme 1.

As a continuation of our works, herein we present the corresponding synthesis and structural characterization of the lanthanide(III) complexes of the related monobracchial receptor $N$-(2-salicylaldiminatobenzyl)-1-aza18-crown-6 $\left(\mathbf{L}^{4}\right)$ shown in Scheme 1. The study of $\mathbf{L n}(\mathrm{III})$ complexes of this receptor allows to evaluate the effect that the absence of one arm may have on the coordination ability of the receptor. From the structural 
point of view this receptor derives from $\mathbf{L}^{1}$ by loss of one 2-salicylaldiminato-benzyl pendant and replacement of the corresponding pivotal nitrogen atom by an oxygen donor. The complexes have been also characterized by $a b$ initio calculations at the $\mathrm{HF} / 3-21 \mathrm{G}^{*}$ level. The crystal structures of the corresponding praseodymium and samarium compounds were determined by X-ray crystallography.

\section{Experimental}

\subsection{Reagents}

Lanthanide(III) perchlorates hydrates ( $\mathrm{La}-\mathrm{Lu}$, excluding $\mathrm{Pm}$ ) were purchased from Alfa laboratories, either as solid samples ( $\mathrm{La}$ and $\mathrm{Ce}$ ) or as $50 \% \mathrm{w} / \mathrm{w}$ aqueous solutions. All other chemicals were purchased from commercial sources and used without further purification. Solvents were of reagent grade and were purified by the usual methods. Acetonitrile- $d_{3}$ for NMR measurements (Merck, 99\% D) was used as received. Caution! Although we have experienced no difficulties with the perchlorate salts, they are potentially explosive when combined with organic ligands and should be handled in small quantity and with the necessary precautions [13].

\subsection{Synthesis}

\subsection{1. $N$-(2-Aminobenzyl)-1-aza-18-crown-6 (pL $\left.\mathbf{L}^{4}\right)$}

2-Nitrobenzyl chloride $(0.65 \mathrm{~g}, 3.79 \mathrm{mmol}), 1$-aza-18-crown-6 $(1.00 \mathrm{~g}, 3.79 \mathrm{mmol})$ and $\mathrm{Na}_{2} \mathrm{CO}_{3}(1.20 \mathrm{~g}$, $20 \mathrm{mmol})$ in acetonitrile $(40 \mathrm{~mL})$ were stirred and refluxed for $24 \mathrm{~h}$. The mixture was filtered, the filtrate concentrated to dryness, and the yellow oily residue extracted with $\mathrm{CH}_{2} \mathrm{Cl}_{2} /$ water. The organic phase was dried over anhydrous $\mathrm{MgSO}_{4}$ and concentrated under reduced pressure. The resulting yellow oil was dissolved in absolute ethanol $(60 \mathrm{~mL})$ and $\mathrm{Pd} / \mathrm{C}$ added. Hydrazine hydrate $(0.7 \mathrm{~mL})$ was slowly added and the reaction mixture was heated and stirred for $1 \mathrm{~h}$. After filtration and evaporation of the solvent, the resulting crude product was purified by column chromatography (basic aluminium oxide, $\mathrm{CH}_{2} \mathrm{Cl}_{2}$ ) to afford the desired product as a pale yellow oil. ${ }^{1} \mathrm{H}$ NMR $\left(500 \mathrm{MHz}, \mathrm{CD}_{3} \mathrm{Cl} ; \delta, \mathrm{ppm}\right): 7.0(\mathrm{t}, 1 \mathrm{H}, \operatorname{arH}), 6.9(\mathrm{~d}, 1 \mathrm{H}$, $\operatorname{arH}), 6.6(\mathrm{~m}, 2 \mathrm{H}, \operatorname{arH}), 4.7\left(\mathrm{~b}, 2 \mathrm{H},-\mathrm{NH}_{2}\right), 3.6\left(\mathrm{~m}, 20 \mathrm{H},-\mathrm{CH}_{2}-\right), 2.7\left(\mathrm{~m}, 6 \mathrm{H},-\mathrm{CH}_{2}-\right)$. MS FAB: $m / z=369$ $\left(\mathrm{pL}^{4}+\mathrm{H}\right) . \mathrm{IR}(\mathrm{KBr}): v=v\left(\mathrm{NH}_{2}\right) 3432,3353 \mathrm{~cm}^{-1}$.

\subsubsection{Preparation of the complexes}

A stoichiometric amount (1:1) of $N$-(2-aminobenzyl)-1-aza-18-crown-6 ( $\left.\mathbf{p} \mathbf{L}^{4}\right)$ and salicylaldehyde was dissolved in 2-propanol $(30 \mathrm{~mL})$ and heated to reflux. After $1 \mathrm{~h}$, a solution of equimolar quantity of triethylamine in $10 \mathrm{~mL}$ of 2-propanol was added, and the reflux was maintained for $30 \mathrm{~min}$. A solution of the corresponding hydrated lanthanide(III) perchlorate (equimolar) in $25 \mathrm{~mL}$ of the same solvent was then added and the resultant solution was refluxed for $3 \mathrm{~h}$, filtered while hot and the filtrate left to evaporate slowly at room temperature to yield yellow solids that were collected by filtration and dried under vacuum over $\mathrm{CaCl}_{2}$.

$\left[\mathrm{La}\left(\mathrm{L}^{4}\right)\left(\mathrm{H}_{2} \mathrm{O}\right)\right]\left(\mathrm{ClO}_{4}\right)_{2} \cdot 0.5 \mathrm{C}_{3} \mathrm{H}_{8} \mathrm{O} \quad(\mathbf{1}): \quad N$-(2-aminobenzyl)-1-aza-18-crown-6 $\quad(0.068 \mathrm{~g}, \quad 0.160 \mathrm{mmol})$, salicylaldehyde $(0.019 \mathrm{~g}, 0.160 \mathrm{mmol})$, triethylamine $(0.016 \mathrm{~g}, 0.160 \mathrm{mmol})$ and $\mathrm{La}\left(\mathrm{ClO}_{4}\right)_{3} \cdot 6 \mathrm{H}_{2} \mathrm{O}(0.086 \mathrm{~g}$, $0.160 \mathrm{mmol}$ ) (yield: $0.050 \mathrm{~g}, 36 \%$ ). Anal. Calc. for $\mathrm{C}_{26} \mathrm{H}_{35} \mathrm{Cl}_{2} \mathrm{LaN}_{2} \mathrm{O}_{14} \cdot \mathrm{H}_{2} \mathrm{O} \cdot 0.5 \mathrm{C}_{3} \mathrm{H}_{8} \mathrm{O}$ (857.42): C, 38.5; $\mathrm{H}, 4.8$; N, 3.3. Found: C, 39.2; H, 4.5; N, 3.0\%. MS (FAB): $m / z=709\left[\mathrm{La}\left(\mathrm{L}^{4}\right)\left(\mathrm{ClO}_{4}\right)\right]^{+}$. IR $(\mathrm{KBr}): v=v(\mathrm{C}=$ $\mathrm{N})_{\text {imine }} 1614, v_{\text {as }}(\mathrm{ClO}) 1098, \delta_{\text {as }}(\mathrm{O}-\mathrm{Cl}-\mathrm{O}) 623 \mathrm{~cm}^{-1}$. $\Lambda_{\mathrm{M}}\left(\right.$ acetonitrile, $\left.\mathrm{cm}^{2} \Omega^{-1} \mathrm{~mol}^{-1}\right): 280(2: 1$ electrolyte $)$.

$\left[\mathrm{Ce}\left(\mathrm{L}^{4}\right)\left(\mathrm{H}_{2} \mathrm{O}\right)\right]\left(\mathrm{ClO}_{4}\right)_{2} \quad$ (2): $N$-(2-aminobenzyl)-1-aza-18-crown-6 (0.052 g, $\left.0.140 \mathrm{mmol}\right)$, salicylaldehyde $(0.017 \mathrm{~g}, 0.140 \mathrm{mmol})$, triethylamine $(0.014 \mathrm{~g}, 0.140 \mathrm{mmol})$ and $\mathrm{Ce}\left(\mathrm{ClO}_{4}\right)_{3} \cdot 6 \mathrm{H}_{2} \mathrm{O}(0.077 \mathrm{~g}, 0.140 \mathrm{mmol})$ (yield: $0.051 \mathrm{~g}, 44 \%$ ). Anal. Calc. for $\mathrm{C}_{26} \mathrm{H}_{35} \mathrm{CeCl}_{2} \mathrm{~N}_{2} \mathrm{O}_{14} \cdot \mathrm{H}_{2} \mathrm{O}$ (828.6): C, 37.7; H, 4.5; N, 3.4. Found: C, 
37.7; H, 4.6; N, 3.1\%. MS (FAB): $m / z=710\left[\mathrm{Ce}\left(\mathrm{L}^{4}\right)\left(\mathrm{ClO}_{4}\right)\right]^{+}$. IR $(\mathrm{KBr}): v=v(\mathrm{C}=\mathrm{N})_{\text {imine }} 1609, v_{\text {as }}(\mathrm{ClO})$ $1084, \delta_{\text {as }}(\mathrm{O}-\mathrm{Cl}-\mathrm{O}) 623 \mathrm{~cm}^{-1} . \Lambda_{\mathrm{M}}\left(\right.$ acetonitrile, $\left.\mathrm{cm}^{2} \Omega^{-1} \mathrm{~mol}^{-1}\right): 256$ (2:1 electrolyte).

$\left[\operatorname{Pr}\left(\mathrm{L}^{4}\right)\left(\mathrm{H}_{2} \mathrm{O}\right)\right]\left(\mathrm{ClO}_{4}\right)_{2} \quad$ (3): $N$-(2-aminobenzyl)-1-aza-18-crown-6 $(0.070 \mathrm{~g}, 0.190 \mathrm{mmol})$, salicylaldehyde $(0.023 \mathrm{~g}, 0.190 \mathrm{mmol})$, triethylamine $(0.019 \mathrm{~g}, 0.190 \mathrm{mmol})$ and $\operatorname{Pr}\left(\mathrm{ClO}_{4}\right)_{3} \cdot x \mathrm{H}_{2} \mathrm{O}(0.208 \mathrm{~g}, 0.190 \mathrm{mmol})$ (yield: 0.050 g, 32\%). Anal. Calc. for $\mathrm{C}_{26} \mathrm{H}_{35} \mathrm{Cl}_{2} \mathrm{~N}_{2} \mathrm{O}_{14} \mathrm{Pr} \cdot \mathrm{H}_{2} \mathrm{O}$ (829.39): C, 37.7; H, 4.9; N, 3.4. Found: C, 37.7; H, 5.2; N, 3.1\%. MS (FAB): $m / z=711\left[\operatorname{Pr}\left(\mathrm{L}^{4}\right)\left(\mathrm{ClO}_{4}\right)\right]^{+}$. IR $(\mathrm{KBr}): v=v(\mathrm{C}=\mathrm{N})_{\text {imine }} 1609, v_{\mathrm{as}}(\mathrm{ClO})$ $1083, \delta_{\text {as }}(\mathrm{O}-\mathrm{Cl}-\mathrm{O}) 623 \mathrm{~cm}^{-1} . \Lambda_{\mathrm{M}}$ (acetonitrile, $\left.\mathrm{cm}^{2} \Omega^{-1} \mathrm{~mol}^{-1}\right): 267$ (2:1 electrolyte). X-ray quality crystals of formula $\left[\mathrm{Pr}\left(\mathrm{L}^{4}\right)\left(\mathrm{H}_{2} \mathrm{O}\right)\right]\left(\mathrm{ClO}_{4}\right)_{2} \cdot \mathrm{H}_{2} \mathrm{O} \cdot \mathrm{C}_{3} \mathrm{H}_{8} \mathrm{O}$ were grown by slow diffusion of diethyl ether into a solution of $\mathbf{3}$ in 2-propanol.

$\left[\mathrm{Nd}\left(\mathrm{L}^{4}\right)\left(\mathrm{H}_{2} \mathrm{O}\right)\right]\left(\mathrm{ClO}_{4}\right)_{2}$ (4): $N$-(2-aminobenzyl)-1-aza-18-crown-6 $(0.052 \mathrm{~g}, 0.140 \mathrm{mmol})$, salicylaldehyde $(0.017 \mathrm{~g}, 0.140 \mathrm{mmol})$, triethylamine $(0.014 \mathrm{~g}, 0.140 \mathrm{mmol})$ and $\mathrm{Nd}\left(\mathrm{ClO}_{4}\right)_{3} \cdot x \mathrm{H}_{2} \mathrm{O}(0.155 \mathrm{~g}, 0.140 \mathrm{mmol})$ (yield: 0.090 g, 77\%). Anal. Calc. for $\mathrm{C}_{26} \mathrm{H}_{35} \mathrm{Cl}_{2} \mathrm{~N}_{2} \mathrm{Nd} \mathrm{O}_{14} \cdot \mathrm{H}_{2} \mathrm{O}$ (832.72): C, 37.5; H, 4.9; N, 3.4. Found: C, 37.8; H, 5.2; N, 3.1\%. MS (FAB): $m / z=712\left[\mathrm{Nd}\left(\mathrm{L}^{4}\right)\left(\mathrm{ClO}_{4}\right)\right]^{+}$. IR $(\mathrm{KBr}): v=v(\mathrm{C}=\mathrm{N})_{\text {imine }} 1609, v_{\mathrm{as}}(\mathrm{ClO})$ $1088, \delta_{\text {as }}(\mathrm{O}-\mathrm{Cl}-\mathrm{O}) 623 \mathrm{~cm}^{-1} . \Lambda_{\mathrm{M}}$ (acetonitrile, $\left.\mathrm{cm}^{2} \Omega^{-1} \mathrm{~mol}^{-1}\right): 297$ (2:1 electrolyte).

$\left[\mathrm{Sm}\left(\mathrm{L}^{4}\right)\left(\mathrm{H}_{2} \mathrm{O}\right)\right]\left(\mathrm{ClO}_{4}\right)_{2}(\mathbf{5}): N$-(2-aminobenzyl)-1-aza-18-crown-6 $(0.048 \mathrm{~g}, 0.130 \mathrm{mmol})$, salicylaldehyde $(0.016 \mathrm{~g}, 0.130 \mathrm{mmol})$, triethylamine $(0.013 \mathrm{~g}, 0.130 \mathrm{mmol})$ and $\mathrm{Sm}\left(\mathrm{ClO}_{4}\right)_{3} \cdot x \mathrm{H}_{2} \mathrm{O}(0.148 \mathrm{~g}, 0.130 \mathrm{mmol})$ (yield: $0.035 \mathrm{~g}, 32 \%$ ). Anal. Calc. for $\mathrm{C}_{26} \mathrm{H}_{35} \mathrm{Cl}_{2} \mathrm{~N}_{2} \mathrm{O}_{14} \mathrm{Sm} \cdot \mathrm{H}_{2} \mathrm{O}$ (838.83): C, 37.2; H, 4.5; N, 3.3. Found: C, 37.1; H, 5.0; N, 3.2\%. MS (FAB): $m / z=722\left[\mathrm{Sm}\left(\mathrm{L}^{4}\right)\left(\mathrm{ClO}_{4}\right)\right]^{+}$. IR $(\mathrm{KBr}): v=v(\mathrm{C}=\mathrm{N})_{\text {imine }} 1614, v_{\text {as }}(\mathrm{ClO})$ $1093, \delta_{\text {as }}(\mathrm{O}-\mathrm{Cl}-\mathrm{O}) 623 \mathrm{~cm}^{-1} . \Lambda_{\mathrm{M}}$ (acetonitrile, $\left.\mathrm{cm}^{2} \Omega^{-1} \mathrm{~mol}^{-1}\right): 269$ (2:1 electrolyte). X-ray quality crystals of formula $\left[\mathrm{Sm}\left(\mathrm{L}^{4}\right)\left(\mathrm{H}_{2} \mathrm{O}\right)\right]\left(\mathrm{ClO}_{4}\right)_{2} \cdot \mathrm{C}_{3} \mathrm{H}_{8} \mathrm{O}$ were grown by slow diffusion of diethyl ether into a solution of 5 in 2-propanol.

$\left[\mathrm{Eu}\left(\mathrm{L}^{4}\right)\left(\mathrm{H}_{2} \mathrm{O}\right)\right]\left(\mathrm{ClO}_{4}\right)_{2} \cdot 3 \mathrm{H}_{2} \mathrm{O} \quad(\mathbf{6}): \quad N$-(2-aminobenzyl)-1-aza-18-crown-6 $\quad(0.062 \mathrm{~g}, \quad 0.170 \mathrm{mmol})$, salicylaldehyde $(0.021 \mathrm{~g}, 0.170 \mathrm{mmol})$, triethylamine $(0.017 \mathrm{~g}, 0.170 \mathrm{mmol})$ and $\mathrm{Eu}\left(\mathrm{ClO}_{4}\right)_{3} \cdot x \mathrm{H}_{2} \mathrm{O}(0.188 \mathrm{~g}$, 0.170 mmol) (yield: $0.015 \mathrm{~g}, 10 \%$ ). Anal. Calc. for $\mathrm{C}_{26} \mathrm{H}_{35} \mathrm{Cl}_{2} \mathrm{EuN}_{2} \mathrm{O}_{14} \cdot 4 \mathrm{H}_{2} \mathrm{O}$ (894.44): C, 34.9; $\mathrm{H}, 4.8 ; \mathrm{N}$, 3.1. Found: $\mathrm{C}, 35.0 ; \mathrm{H}, 4.8 ; \mathrm{N}, 3.1 \%$. MS $(\mathrm{FAB}): m / z=723\left[\mathrm{Eu}\left(\mathrm{L}^{4}\right)\left(\mathrm{ClO}_{4}\right)\right]^{+}$. IR $(\mathrm{KBr}): v=v(\mathrm{C}=$ $\mathrm{N})_{\text {imine }} 1609, v_{\text {as }}(\mathrm{ClO}) 1085, \delta_{\text {as }}(\mathrm{O}-\mathrm{Cl}-\mathrm{O}) 623 \mathrm{~cm}^{-1}$.

$\left[\mathrm{Gd}\left(\mathrm{L}^{4}\right)\left(\mathrm{H}_{2} \mathrm{O}\right)\right]\left(\mathrm{ClO}_{4}\right)_{2} \cdot \mathrm{H}_{2} \mathrm{O} \quad$ (7): $\quad N$-(2-aminobenzyl)-1-aza-18-crown-6 $\quad(0.059 \mathrm{~g}, \quad 0.160 \mathrm{mmol})$, salicylaldehyde $(0.019 \mathrm{~g}, 0.160 \mathrm{mmol})$, triethylamine $(0.016 \mathrm{~g}, 0.160 \mathrm{mmol})$ and $\mathrm{Gd}\left(\mathrm{ClO}_{4}\right)_{3} \cdot x \mathrm{H}_{2} \mathrm{O}(0.080 \mathrm{~g}$, 0.160 mmol) (yield: $0.030 \mathrm{~g}, 22 \%$ ). Anal. Calc. for $\mathrm{C}_{26} \mathrm{H}_{35} \mathrm{Cl}_{2} \mathrm{GdN}_{2} \mathrm{O}_{14} \cdot 2 \mathrm{H}_{2} \mathrm{O}$ (863.73): C, 36.1; $\mathrm{H}, 4.6$; $\mathrm{N}$, 3.2. Found: C, 36.0; H, 4.5; N, 3.2\%. MS (FAB): $m / z=728\left[\mathrm{Gd}\left(\mathrm{L}^{4}\right)\left(\mathrm{ClO}_{4}\right)\right]^{+}$. IR $(\mathrm{KBr}): v=v(\mathrm{C}=$ $\mathrm{N})_{\text {imine }} 1609, v_{\text {as }}(\mathrm{ClO}) 1084, \delta_{\text {as }}(\mathrm{O}-\mathrm{Cl}-\mathrm{O}) 623 \mathrm{~cm}^{-1}$. $\Lambda_{\mathrm{M}}\left(\right.$ acetonitrile, $\left.\mathrm{cm}^{2} \Omega^{-1} \mathrm{~mol}^{-1}\right): 259$ (2:1 electrolyte).

$\left[\mathrm{Tb}\left(\mathrm{L}^{4}\right)\left(\mathrm{H}_{2} \mathrm{O}\right)\right]\left(\mathrm{ClO}_{4}\right)_{2} \cdot \mathrm{H}_{2} \mathrm{O} \quad(\mathbf{8}): \quad N$-(2-aminobenzyl)-1-aza-18-crown-6 $\quad(0.052 \mathrm{~g}, \quad 0.140 \mathrm{mmol})$, salicylaldehyde $(0.017 \mathrm{~g}, 0.140 \mathrm{mmol})$, triethylamine $(0.014 \mathrm{~g}, 0.140 \mathrm{mmol})$ and $\mathrm{Tb}\left(\mathrm{ClO}_{4}\right)_{3} \cdot x \mathrm{H}_{2} \mathrm{O}(0.163 \mathrm{~g}$, 0.140 mmol) (yield: $0.022 \mathrm{~g}, 18 \%$ ). Anal. Calc. for $\mathrm{C}_{26} \mathrm{H}_{35} \mathrm{Cl}_{2} \mathrm{~N}_{2} \mathrm{O}_{14} \mathrm{~Tb} \cdot 2 \mathrm{H}_{2} \mathrm{O}$ (863.73): C, 36.1; $\mathrm{H}, 4.5 ; \mathrm{N}$, 3.2. Found: $\mathrm{C}, 36.0 ; \mathrm{H}, 4.4 ; \mathrm{N}, 3.1 \%$. MS (FAB): $m / z=729\left[\mathrm{~Tb}\left(\mathrm{~L}^{4}\right)\left(\mathrm{ClO}_{4}\right)\right]^{+}$. IR $(\mathrm{KBr}): v=v(\mathrm{C}=$ $\mathrm{N})_{\text {imine }} 1609, v_{\text {as }}(\mathrm{ClO}) 1083, \delta_{\text {as }}(\mathrm{O}-\mathrm{Cl}-\mathrm{O}) 623 \mathrm{~cm}^{-1} . \Lambda_{\mathrm{M}}\left(\right.$ acetonitrile, $\left.\mathrm{cm}^{2} \Omega^{-1} \mathrm{~mol}^{-1}\right): 260$ (2:1 electrolyte).

\section{3. $\underline{\text { Measurements }}$}

Elemental analyses were carried out on a Carlo Erba 1108 elemental analyzer. FAB-mass spectra were recorded using a FISONS QUATRO mass spectrometer with Cs ion-gun and 3-nitrobenzylalcohol as a matrix. ${ }^{1} \mathrm{H}$ and ${ }^{13} \mathrm{C}$ NMR spectra were run at $25{ }^{\circ} \mathrm{C}$ with Bruker AC200 $\mathrm{F}$ and Bruker WM-500 spectrometers. Chemical shifts are reported in parts per million with respect to TMS. Spectral assignments were based in part on two-dimensional COSY and NOESY experiments. IR-spectra were recorded, from $\mathrm{KBr}$ discs, using a Bruker Vector 22 spectrophotometer. Conductivity measurements were carried out at $20{ }^{\circ} \mathrm{C}$ with a Crison Micro CM 2201 conductimeter using $10^{-3} \mathrm{M}$ solutions of the complexes in acetonitrile. 


\subsection{X-ray crystallography}

Three-dimensional X-ray data were collected on a Bruker Smart 1000 CCD for compound 3 and on a Bruker X8 APEXII CCD for compound 5. Data were corrected for Lorentz and polarization effects and for absorption by semiempirical methods [14] based on symmetry-equivalent reflections. Complex scattering factors were taken from the program shelx97 [15] included in the wingx program system [16] as implemented on a Pentium ${ }^{\circledR}$ computer. The structure was solved by Patterson methods (dirdif99) [17] and refined by full-matrix least-squares on $F^{2}$. Hydrogen atoms were included in calculated positions and refined in a riding mode, except the hydrogen atoms of the coordinated water molecule, which were first located in a difference electron-density map, fixed to the oxygen atom $\mathrm{O}(7)$, and then left to refine freely in the final stages of refinement in both cases. In 5 the position of the hydrogen atom of the $-\mathrm{OH}$ group of the 2propanol molecule was fixed. Refinement converged with anisotropic displacement parameters for all nonhydrogen atoms. The crystal of $\mathbf{3}$ presents disorders in one perchlorate ion and in some atoms of the crown moiety. These disorders have been solved, and two atomic sites for $\mathrm{O}(20), \mathrm{O}(22), \mathrm{O}(23), \mathrm{C}(17), \mathrm{C}(18)$, $\mathrm{C}(19), \mathrm{C}(20), \mathrm{O}(3)$ have been observed and refined. The sites occupancy factors were $0.70(3)$ for $\mathrm{O}(20 \mathrm{~A})$, $\mathrm{O}(22 \mathrm{~A}), \mathrm{O}(23 \mathrm{~A})$, and $0.537(10)$ for $\mathrm{C}(17 \mathrm{~A}), \mathrm{C}(18 \mathrm{~A}), \mathrm{C}(19 \mathrm{~A}), \mathrm{C}(20 \mathrm{~A}), \mathrm{O}(3 \mathrm{~A})$. The crystal of 5 present a disordered perchlorate group and 34 least-squares restraints had to be imposed to resolve the disorder. The site occupancy factor was 0.82 for $\mathrm{Cl}(2 \mathrm{BA}), \mathrm{O}(12 \mathrm{~A}), \mathrm{O}(13 \mathrm{~A}), \mathrm{O}(14 \mathrm{~A})$, and $\mathrm{O}(15 \mathrm{~A})$. Crystal data and details on data collection and refinement are summarised in Table 1.

Table 1. Crystal data and refinement details for $\mathbf{3}$ and $\mathbf{5}$.

\begin{tabular}{|c|c|c|}
\hline & 3 & 5 \\
\hline Formula & $\mathrm{C}_{29} \mathrm{H}_{47} \mathrm{Cl}_{2} \mathrm{~N}_{2} \mathrm{O}_{17} \mathrm{Pr}$ & $\mathrm{C}_{29} \mathrm{H}_{45} \mathrm{Cl}_{2} \mathrm{~N}_{2} \mathrm{O}_{16} \mathrm{Sm}$ \\
\hline Mol. mass $\left(\mathrm{g} \mathrm{mol}^{-1}\right)$ & 907.5 & 898.92 \\
\hline Crystal system & monoclinic & monoclinic \\
\hline Space group & $P 2_{1} / n$ & $P 2_{1} / c$ \\
\hline$T(\mathrm{~K})$ & $120(2)$ & $100.0(2)$ \\
\hline$a(\AA)$ & $12.193(2)$ & $16.8602(6)$ \\
\hline$b(\AA)$ & $21.949(4)$ & $10.0417(3)$ \\
\hline$c(\AA)$ & $14.213(2)$ & $21.4404(7)$ \\
\hline$\beta\left(^{\circ}\right)$ & $106.000(3)$ & $96.390(1)$ \\
\hline$V\left(\AA^{3}\right)$ & $3656.4(10)$ & $3607.4(2)$ \\
\hline$F\left(\begin{array}{lll}0 & 0 & 0\end{array}\right)$ & 1856 & 1828 \\
\hline$Z$ & 4 & 4 \\
\hline$\lambda(\operatorname{Mo~K} \alpha)(\AA)$ & 0.71073 & 0.71073 \\
\hline$\rho_{\text {calc }}\left(\mathrm{g} \mathrm{cm}^{-3}\right)$ & 1.649 & 1.655 \\
\hline$\mu\left(\mathrm{mm}^{-1}\right)$ & 1.555 & 1.849 \\
\hline$\theta$ Range $\left(^{\circ}\right)$ & $1.76-27.16$ & $1.22-28.3$ \\
\hline$R_{\text {int }}$ & 0.0496 & 0.033 \\
\hline Measured reflections & 32963 & 49500 \\
\hline Unique reflections & 8045 & 8861 \\
\hline Observed reflections $[I>2 \sigma(I)]$ & 5995 & 7833 \\
\hline Goodness-of-fit on $F^{2}$ & 1.07 & 1.137 \\
\hline$R_{1}[I>2 \sigma(I)]^{a}$ & 0.0381 & 0.0265 \\
\hline$w R_{2}(\text { all data })^{b}$ & 0.0899 & 0.0801 \\
\hline Largest differences peak and hole $\left(\mathrm{e} \AA^{-3}\right.$ ) & 1.116 and -1.101 & 1.677 and -1.141 \\
\hline
\end{tabular}

${ }^{a} R_{1}=\sum\left\|F_{0}|-| F_{c}\right\| / \sum\left|F_{0}\right| .{ }^{b} w R_{2}=\left\{\sum\left[w\left(\left.|| F_{0}\right|^{2}-\left|F_{c}\right|^{2}\right)^{2}\right] / \sum\left[w\left(F_{0}^{4}\right)\right]\right\}^{1 / 2}$. 


\subsection{Computational methods}

Full geometry optimizations of the $\left[\operatorname{Ln}\left(\mathrm{L}^{4}\right)\left(\mathrm{H}_{2} \mathrm{O}\right)\right]^{2+}$ systems $(\mathrm{Ln}=\mathrm{La}, \mathrm{Pr}, \mathrm{Sm}$, Ho, Lu) were performed in vacuo at the RHF level. For these calculations the effective core potential (ECP) of Dolg et al. and the related [5s4p3d]-GTO valence basis set were used for the lanthanides [18], while the 3-21G* basis set was used for the ligand atoms. The X-ray structure of compound $\mathbf{3}$ was used as input geometry for each geometry optimization. The two conformations observed in the solid state for compound $\mathbf{3}$ were considered. The relative free energies of the two conformers of $\left[\mathrm{Ln}\left(\mathrm{L}^{4}\right)\left(\mathrm{H}_{2} \mathrm{O}\right)\right]^{2+}$ complexes were calculated in vacuo at the same computational level, and they include non-potential energy contributions (that is, zero point energy an thermal terms) obtained by frequency analysis. The nature of the calculated stationary points as true minima was checked by frequency analysis. All HF calculations were performed by using the gaussian 98 package (Revision A.11.3) [19].

\section{Results and discussion}

Reaction of $\mathbf{H L}^{4}$ [prepared in situ by the condensation of $N$-2-aminobenzyl-1-aza-18-crown-6 and salicylaldehyde] with triethylamine and the corresponding hydrated lanthanide perchlorate in 2-propanol led to complexes of formula $\left[\mathrm{Ln}\left(\mathrm{L}^{4}\right)\left(\mathrm{H}_{2} \mathrm{O}\right)\right]\left(\mathrm{ClO}_{4}\right)_{2} \cdot x \operatorname{solv}(\mathrm{Ln}=\mathrm{La}-\mathrm{Tb}$, excluding Pm). Attempts to prepare the corresponding complexes of the heaviest $\mathrm{Ln}(\mathrm{III})$ ions $(\mathrm{Ln}=\mathrm{Dy}-\mathrm{Lu})$ under analogous conditions were unsuccessful. The IR and FAB mass spectra of the complexes confirmed the formation of the Schiff-base armed macrocycle as well as its presence in the complexes. The IR spectra ( $\mathrm{KBr}$ discs) feature a band attributable to $v(\mathrm{C}=\mathrm{N})_{\text {imine }}$ stretching mode at $c a .1610 \mathrm{~cm}^{-1}$ which, together with the absence of bands due to carbonyl and/or amine vibration modes, confirms the formation of the imine bond. Bands corresponding to the $v_{\text {as }}(\mathrm{Cl}-\mathrm{O})$ stretching and $\delta_{\text {as }}(\mathrm{O}-\mathrm{Cl}-\mathrm{O})$ bending modes of the perchlorate groups appear at $c a .1090$ and $623 \mathrm{~cm}^{-1}$. The absorption at $623 \mathrm{~cm}^{-1}$ clearly shows up without splitting, as befit uncoordinated anions [20]. The FAB-mass spectrum of each complex displays a very intense peak (100\% BPI) corresponding to the $\left[\mathrm{Ln}\left(\mathrm{L}^{4}\right)\left(\mathrm{ClO}_{4}\right)\right]^{+}$fragment. The ${ }^{1} \mathrm{H}$ NMR spectrum of the $\mathrm{La}(\mathrm{III})$ diamagnetic complex 1 recorded in acetonitrile- $d_{3}$ solution shows broad signals for the protons of the macrocyclic unit, while the signals corresponding to protons of the pendant arm are well resolved. The later signals could be assigned with the aid of the 2D COSY and NOESY spectra (see scheme 1 for labelling): $\delta 8.28$ (s, 1H, H7), 7.57 (m, 1H, H12), 7.55 (m, 1H, H10), 7.47 (m, 2H, H5 and H3), 7.35 (ddd, 1H, H11), 7.28 (dd, 1H, H9), 7.78 (m, 2H, H2 and $\mathrm{H} 4)$. The NOESY spectrum gives a strong cross-peak relating $\mathrm{H} 7$ and $\mathrm{H} 5(\mathrm{H} 7 \cdots \mathrm{H} 5=2.37 \AA$ in the X-ray structure of 5) and a weaker signal relating $\mathrm{H} 7$ and $\mathrm{H} 9(\mathrm{H} 7 \cdots \mathrm{H} 9=2.52 \AA$ in the X-ray structure of 5). The spectrum does not show signals attributable to the carbonyl and amine precursors, in agreement with the formation of the expected complex. The broad signals observed for the proton nuclei of the crown moiety indicate the presence of a conformational equilibrium in solution due to the flexibility of the macrocyclic unit.

The solid state structures of the praseodymium and samarium complexes have been determined by X-ray diffraction studies. Crystals consist of the $\left[\operatorname{Ln}\left(\mathrm{L}^{4}\right)\left(\mathrm{H}_{2} \mathrm{O}\right)\right]^{2+}$ cations $(\mathrm{Ln}=\mathrm{Pr}$ or $\mathrm{Sm})$, two well-separated perchlorate anions, and solvent molecules (2-propanol in both crystals, and also water in the praseodymium complex) hydrogen bonded to the coordinated water molecule. Fig. 1 displays a view of the structures of the cations. In the case of the $\left[\operatorname{Pr}\left(\mathrm{L}^{4}\right)\left(\mathrm{H}_{2} \mathrm{O}\right)\right]^{2+}$ complex the carbon atoms $\mathrm{C}(17), \mathrm{C}(18), \mathrm{C}(19)$ and $\mathrm{C}(20)$, as well as the oxygen atom of the crown moiety $\mathrm{O}(3)$ are disordered. It is well known that crown and aza-crown ethers may take several slightly different conformations in the solid state [21]. These different conformations are not always resolved by X-ray determinations, which often yield an average representation of the unit cell. In the $\operatorname{Pr}(\mathrm{III})$ complex two different conformations of the crown moiety are well resolved by the X-ray determination $[10,11]$. By contrast, only one conformation of the crown moiety is observed in the $\mathrm{Sm}$ (III) 
complex. This conformation corresponds to that observed for the $\operatorname{Pr}(\mathrm{III})$ complex taking into account the sites labeled as A in Fig. 1.
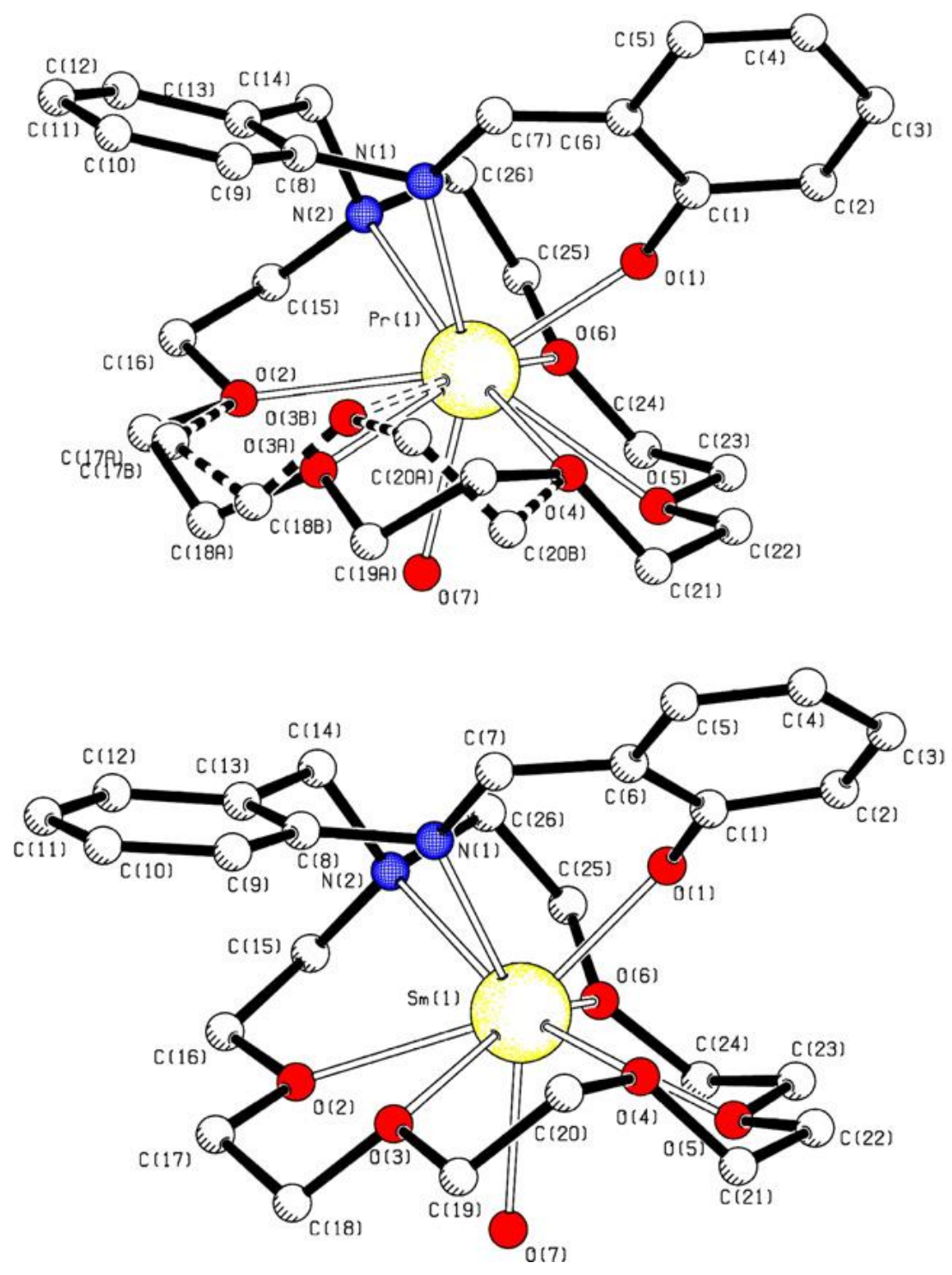

Fig. 1. X-ray crystal structures of the $\left[\operatorname{Pr}\left(\mathrm{L}^{4}\right)\left(\mathrm{H}_{2} \mathrm{O}\right)\right]^{2+}$ and $\left[\mathrm{Sm}\left(\mathrm{L}^{4}\right)\left(\mathrm{H}_{2} \mathrm{O}\right)\right]^{2+}$ cations present in 3 (top) and $\mathbf{5}$ (bottom). Hydrogen atoms are omitted for simplicity.

Bond distances of the metal coordination environment in $\left[\mathrm{Ln}\left(\mathrm{L}^{4}\right)\left(\mathrm{H}_{2} \mathrm{O}\right)\right]^{2+}$ complexes $(\mathrm{Ln}=\mathrm{Pr}$ or $\mathrm{Sm})$ are given in Table 2, while bond angles of the metal coordination environment are given in Table S1 (Supporting Information). The lanthanide ion is coordinated to the eight available donor atoms of the ligand and to the oxygen atom of an inner-sphere water molecule. The coordinated water molecule is located on the opposite side of the crown moiety with respect to the pendant arm. The metal ion is almost symmetrically positioned with respect to the crown cavity. The Ln-crown donors distances (Table 2) fall in the range between 2.5052.679 (Pr) and 2.435-2.634 $\AA$ (Sm), and they are similar to the distance between the $\mathrm{Ln}(\mathrm{III})$ ion and the oxygen atom of the coordinated water molecule [2.503(5) (Pr) and 2.446(2) $\AA$ (Sm)] and Ln-imine nitrogen [2.567(3) (Pr) and 2.519(2) $\AA$ (Sm)] bond lengths. The distance to the phenolate oxygen donor atom is clearly shorter than the remaining bond distances of the $\operatorname{Ln}(\mathrm{III})$ coordination sphere $[\operatorname{Pr}(1)-\mathrm{O}(1) 2.257$ (3) $\AA$; $\mathrm{Sm}(1)-\mathrm{O}(1) 2.2461(19) \AA]$. The bond distances of the metal coordination environment in $\left[\operatorname{Pr}\left(\mathrm{L}^{4}\right)\left(\mathrm{H}_{2} \mathrm{O}\right)\right]^{2+}$ are 
slightly shorter than those found in the related complex with the bibracchial receptor $\mathbf{L}^{1},\left[\operatorname{Pr}\left(\mathrm{L}^{1}\right)\right]^{+}[10]$. However, this is expected because the $\operatorname{Pr}(\mathrm{IIII})$ ion is 10 -coordinate in $\left[\operatorname{Pr}\left(\mathrm{L}^{1}\right)\right]^{+}$, while in $\left[\operatorname{Pr}\left(\mathrm{L}^{4}\right)\left(\mathrm{H}_{2} \mathrm{O}\right)\right]^{2+}$ the metal ion is only nine-coordinate. The Sm-donor distances observed in $\mathbf{5}$ are very similar to those reported for the $\mathrm{Sm}$ (III) complex of $\mathbf{L}^{2}$ (Scheme 1), in which the metal ion is also nine-coordinate. In both $\left[\mathrm{Ln}\left(\mathrm{L}^{4}\right)\left(\mathrm{H}_{2} \mathrm{O}\right)\right]^{2+}$ complexes $(\mathrm{Ln}=\mathrm{Pr}$ or $\mathrm{Sm})$ the oxygen atoms $\mathrm{O}(2), \mathrm{O}(3 \mathrm{~A}), \mathrm{O}(4)$ and $\mathrm{O}(6)$ are essentially coplanar, with a mean deviation from planarity of $0.032(\mathbf{3})$ and $0.0405 \AA(5)$. The pivotal nitrogen donor $\mathrm{N}(2)$ is located 1.664(3) (3) and 1.830(2) $\AA$ (5) above this plane, and the oxygen atom $\mathrm{O}(5)$ is placed 1.040 (3) (3) and 1.098(2) $\AA$ (5) below it. The coordination polyhedron around the metal ion is so severely distorted that it may be viewed both as a monocapped distorted dodecahedron, where atom $\mathrm{O}(2)$ is capping a triangular face of the dodecahedron, or as a monocapped square antiprism comprised of two pseudoplanes defined by $\mathrm{N}(1), \mathrm{N}(2), \mathrm{O}(2), \mathrm{O}(3)$ (lower plane) and $\mathrm{O}(1), \mathrm{O}(4), \mathrm{O}(6), \mathrm{O}(7)$ (upper plane), with the oxygen atom $\mathrm{O}(5)$ capping the latter. On the other hand, the benzene and phenol rings are not coplanar, and they intersect at $56.89(11)^{\circ}(3)$ and $42.42^{\circ}(5)$. Thus, the coordination of the pendant arm to the $\operatorname{Ln}(\mathrm{III})$ ion provokes a loss of planarity of both aromatic rings.

Table 2. Experimental ${ }^{a}$ and calculated ${ }^{b}$ bond lengths $[\AA]$ of the metal coordination environment in $\left[\mathrm{Ln}\left(\mathrm{L}^{4}\right)\left(\mathrm{H}_{2} \mathrm{O}\right)\right]^{2+}$ complexes $(\mathrm{Ln}=\mathrm{La}, \mathrm{Pr}, \mathrm{Sm}, \mathrm{Ho}$ or $\mathrm{Lu})$ and relative free energies $\left[\mathrm{kcal} \mathrm{mol}^{-1}\right]$ of conformation $\mathbf{B}$ with respect to conformation $\mathbf{A}$.

\begin{tabular}{|c|c|c|c|c|c|c|c|c|c|c|c|c|}
\hline & \multirow{2}{*}{\multicolumn{2}{|c|}{$\begin{array}{l}\text { Ln }=\mathbf{L a} \\
\text { Calculated }^{b}\end{array}$}} & \multicolumn{3}{|c|}{$\mathrm{Ln}=\mathbf{P r}$} & \multicolumn{3}{|c|}{$\mathrm{Ln}=\mathrm{Sm}$} & \multirow{2}{*}{\multicolumn{2}{|c|}{$\begin{array}{l}\text { Ln }=\text { Ho } \\
\text { Calculated }^{b}\end{array}$}} & \multirow{2}{*}{\multicolumn{2}{|c|}{$\begin{array}{l}\text { Ln }=\mathbf{L u} \\
\text { Calculated }^{b}\end{array}$}} \\
\hline & & & \multicolumn{2}{|c|}{ Calculated $^{b}$} & \multirow{2}{*}{$\begin{array}{l}\text { Experimental }^{a} \\
\mathbf{A}+\mathbf{B}\end{array}$} & \multicolumn{2}{|c|}{ Calculated $^{b}$} & \multirow{2}{*}{$\begin{array}{l}\text { Experimental }^{a} \\
\mathbf{A} \\
\end{array}$} & & & & \\
\hline & $\mathbf{A}$ & $\mathbf{B}$ & $\mathbf{A}$ & B & & $\mathbf{A}$ & B & & $\mathbf{A}$ & B & $\mathbf{A}$ & B \\
\hline $\mathrm{Ln}(1)-\mathrm{O}(1)$ & 2.338 & 2.312 & 2.303 & 2.280 & $2.257(3)$ & 2.260 & 2.238 & $2.246(2)$ & 2.196 & 2.174 & 2.151 & 2.129 \\
\hline $\operatorname{Ln}(1)-\mathrm{O}(2)$ & 2.642 & 2.683 & 2.612 & 2.646 & $2.628(3)$ & 2.576 & 2.604 & $2.577(2)$ & 2.538 & 2.532 & 2.475 & 2.465 \\
\hline $\operatorname{Ln}(1)-O(3)$ & 2.661 & 2.587 & 2.629 & 2.544 & $\begin{array}{l}2.679(7) \mathrm{O}(3 \mathrm{~A}) \\
2.513(8) \mathrm{O}(3 \mathrm{~B})\end{array}$ & 2.592 & 2.496 & $2.602(2)$ & 2.542 & 2.430 & 2.501 & 2.375 \\
\hline $\operatorname{Ln}(1)-O(4)$ & 2.577 & 2.676 & 2.544 & 2.641 & $2.614(3)$ & 2.505 & 2.607 & $2.527(2)$ & 2.458 & 2.582 & 2.437 & 2.589 \\
\hline $\operatorname{Ln}(1)-\mathrm{O}(5)$ & 2.741 & 2.740 & 2.720 & 2.717 & $2.610(2)$ & 2.697 & 2.704 & $2.593(2)$ & 2.712 & 2.771 & 2.801 & 2.935 \\
\hline $\operatorname{Ln}(1)-O(6)$ & 2.562 & 2.589 & 2.529 & 2.550 & $2.505(3)$ & 2.488 & 2.508 & $2.435(2)$ & 2.436 & 2.457 & 2.405 & 2.428 \\
\hline $\operatorname{Ln}(1)-\mathrm{O}(7)$ & 2.619 & 2.609 & 2.574 & 2.567 & $2.503(3)$ & 2.516 & 2.508 & $2.446(2)$ & 2.430 & 2.420 & 2.362 & 2.351 \\
\hline $\operatorname{Ln}(1)-\mathrm{N}(1)$ & 2.605 & 2.627 & 2.569 & 2.595 & $2.567(3)$ & 2.523 & 2.553 & $2.519(2)$ & 2.455 & 2.485 & 2.404 & 2.429 \\
\hline $\operatorname{Ln}(1)-\mathrm{N}(2)$ & 2.723 & 2.747 & 2.691 & 2.705 & $2.679(3)$ & 2.655 & 2.663 & $2.634(2)$ & 2.608 & 2.606 & 2.570 & 2.552 \\
\hline$A F_{i}^{c}$ & & & 0.022 & 0.019 & & 0.019 & & & & & & \\
\hline$\Delta \mathrm{G} 298 \mathrm{~K}^{d}{ }^{d}$ & & -0.26 & & 0.15 & & & 0.81 & & & 1.55 & & 1.66 \\
\hline
\end{tabular}

${ }^{a}$ From single-crystal X-ray diffraction analyses.

${ }^{b}$ From $a b$ initio calculations at the HF/3-21G* level. Two different geometries labelled as $\mathbf{A}$ and $\mathbf{B}$ were calculated.

${ }^{\mathrm{c}} A F_{i}=\left[\sum(\exp -\mathrm{calcd})^{2} / \sum(\exp )^{2}\right]^{1 / 2}$, where exp and calcd denote experimental and calculated values, respectively.

${ }^{\mathrm{d}} \Delta G_{298 \mathrm{~K}}^{\mathrm{o}}=G_{298 \mathrm{~K}}^{\mathrm{o}}(\mathbf{B})-G_{298 \mathrm{~K}}^{\mathrm{o}}(\mathbf{A})$.

In previous works, we have found that in the $\left[\operatorname{Ln}\left(\mathrm{L}^{1}\right)\right]^{+}$complexes [10] the lanthanide ion is 10-coordinate and deeply buried in the receptor cavity, so that additional ligands such as water molecules are excluded from the metal coordination environment. In spite of their lower denticity, a similar situation occurs for the lanthanide complexes of the bibracchial lariat ethers $N, N^{\prime}$-bis(2-salicylaldiminatobenzyl)-1,10-diaza-15crown-5 $\left(\mathbf{L}^{2}\right)$ and $N, N^{\prime}$-bis(2-salicylaldiminato benzyl)-4,10-diaza-12-crown-4 $\left(\mathbf{L}^{3}\right)$ [11,12], in which the metal ion is nine- or eight-coordinate. However, the $\mathrm{X}$-ray crystal structures of the $\left[\mathrm{Ln}\left(\mathrm{L}^{4}\right)\left(\mathrm{H}_{2} \mathrm{O}\right)\right]^{2+}$ complexes reported here $(\mathrm{Ln}=\operatorname{Pr}$ or $\mathrm{Sm})$ demonstrate that the monobracchial receptor $\mathbf{L}^{4}$ is not able to protect the lanthanide ion from the interaction with water molecules. The inner-sphere water 
molecule coordinates to the $\mathrm{Ln}(\mathrm{III})$ ion in trans position with respect to the donor atoms of the pendant arm. As a consequence the metal ion is placed inside the crown hole, in contrast to the $\operatorname{Ln}(\mathrm{III})$ complexes of the bibracchial lariat ethers $\mathbf{L}^{1}-\mathbf{L}^{3}$ where the metal ion is placed over the plane of the crown moiety [10-12].

The $\left[\mathrm{Ln}\left(\mathrm{L}^{4}\right)\left(\mathrm{H}_{2} \mathrm{O}\right)\right]^{2+}$ systems ( $\left.\mathrm{Ln}=\mathrm{La}, \mathrm{Pr}, \mathrm{Sm}, \mathrm{Ho}, \mathrm{Lu}\right)$ were investigated in vacuo by means of $a b$ initio calculations at the HF/3-21G* level. It has been demonstrated that the use of a more extended basis sets for the ligand atoms or a higher level of theory (B3LYP, MP2) does not result in an improvement of the agreement between experimental (X-ray) and calculated structures [22,23]. As there is not a good allelectron basis set for lanthanides, the effective core potential (ECP) of Dolg et al. and the related [5s4p3d]GTO valence basis set was applied in these calculations [18]. This ECP includes $46+4 \mathrm{f}^{n}$ electrons in the core, leaving the outermost 11 electrons to be treated explicitly, and it has been demonstrated to provide reliable results for the lanthanide aqua-ions [22], several lanthanide chelates with polyamino carboxylate ligands [24] and lanthanide dipicolinates [25]. Recently, we have proved to give excellent results also for lanthanide complexes with pendant-armed crowns [12] or azacrowns [26] and chelates containing pyridine units [27]. Compared to all-electron basis sets, ECPs account to some extent for relativistic effects, which are believed to become important for the elements from the fourth row of the periodic table. Two geometries of the complexes showing the two different conformations of the crown moiety observed in the X-ray structure of the $\operatorname{Pr}(\mathrm{III})$ complex were considered. The conformation denoted as $\mathbf{A}$ corresponds to that observed for the $\operatorname{Pr}(\mathrm{III})$ complex in the solid state taking into account the sites labelled as C(17A), C(18A), C(19A), C(20A), $\mathrm{O}(3 \mathrm{~A})$ in Fig. 1, while the conformation denoted as $\mathbf{B}$ is generated by the occupation of sites $\mathrm{C}(17 \mathrm{~B})$, $\mathrm{C}(18 \mathrm{~B}), \mathrm{C}(19 \mathrm{~B}), \mathrm{C}(20 \mathrm{~B}), \mathrm{O}(3 \mathrm{~B})$. In vacuo optimized Cartesian coordinates obtained for the different $\left[\mathrm{Ln}\left(\mathrm{L}^{4}\right)\left(\mathrm{H}_{2} \mathrm{O}\right)\right]^{2+}$ systems are given in Supporting Information. The optimized geometries obtained for the $\left[\operatorname{Pr}\left(\mathrm{L}^{4}\right)\left(\mathrm{H}_{2} \mathrm{O}\right)\right]^{2+}$ system are shown in Fig. 2.

The $\mathbf{A}$ and $\mathbf{B}$ conformations calculated for the $\left[\operatorname{Pr}\left(\mathrm{L}^{4}\right)\left(\mathrm{H}_{2} \mathrm{O}\right)\right]^{2+}$ system are in good agreement with the experimental geometrical parameters obtained from the X-ray single crystal analysis of compound $\mathbf{3}$. According to Table 2, the calculated distances between the praseodymium ion and the donor atoms are in reasonably good agreement with those observed experimentally (within $0.07 \AA$, except $\operatorname{Pr}-\mathrm{O}(5)$ that deviates $0.11 \AA)$, as evidenced by the excellent agreement factors obtained $\left[A F_{i}=0.022(\mathbf{A})\right.$ and $0.019(\mathbf{B}) ; A F_{i}=$ $\left[\sum(\exp -\mathrm{calcd})^{2} / \sum(\exp )^{2}\right]^{1 / 2}$, where exp and calcd denote experimental and calculated values, respectively) [28]. The $\mathrm{Sm}$-donor distances calculated for conformation $\mathbf{A}$ also show a good agreement with the experimental bond lengths observed in the solid state (within $0.10 \AA, A F_{i}=0.019$ ). The calculated structures for the remaining $\left[\mathrm{Ln}\left(\mathrm{L}^{4}\right)\left(\mathrm{H}_{2} \mathrm{O}\right)\right]^{2+}$ systems investigated $(\mathrm{Ln}=\mathrm{La}, \mathrm{Ho}, \mathrm{Lu})$ are very similar to the experimental and calculated structures found for the Pr(III) and Sm(III) analogues, with a water molecule in the first coordination sphere. The calculated La-donor bond lengths (Table 2) are similar to those found experimentally in the lanthanum complex with the related receptor $\mathbf{L}^{1}[10]$.

The relative free energies of the $\mathbf{A}$ and $\mathbf{B}$ conformations of $\left[\mathrm{Ln}\left(\mathrm{L}^{4}\right)\left(\mathrm{H}_{2} \mathrm{O}\right)\right]^{2+}$ complexes were calculated in vacuo at the HF/3-21G* level, and the results are reported in Table 2 and Fig. 3. Relative free energies were calculated as $\Delta G_{298 \mathrm{~K}}^{\mathrm{o}}=G_{298 \mathrm{~K}}^{\mathrm{o}}(\mathbf{B})-G_{298 \mathrm{~K}}^{\mathrm{O}}(\mathbf{A})$, and therefore a positive relative energy indicates that the $\mathbf{A}$ conformation is more stable than the $\mathbf{B}$ one. Our calculations indicate that the relative energy of conformation $\mathbf{B}$ increases along the lanthanide series. The $\mathbf{A}$ conformation is the most stable one in the case of the $\mathrm{La}(\mathrm{III})$ complex, while for the $\mathrm{Pr}(\mathrm{III}), \mathrm{Sm}(\mathrm{III}), \mathrm{Ho}(\mathrm{III})$ and $\mathrm{Lu}(\mathrm{III})$ complexes the minimum energy conformation corresponds to the $\mathbf{A}$ form. Both $\mathbf{A}$ and $\mathbf{B}$ conformations are observed in the solid state structure of the $\operatorname{Pr}(\mathrm{III})$ complex, while for Sm(III) only the $\mathbf{A}$ form is found, which suggests a stabilization of conformation $\mathbf{A}$ on decreasing the ionic radius of the $\mathrm{Ln}(\mathrm{III})$ ion, as predicted by our quantum mechanical calculations. The relative free energies reported in Table 2 for $\left[\operatorname{Pr}\left(\mathrm{L}^{4}\right)\left(\mathrm{H}_{2} \mathrm{O}\right)\right]^{2+}$ predict a small energy difference between the $\mathbf{A}$ and $\mathbf{B}$ conformations $\left(0.15 \mathrm{kcal} \cdot \mathrm{mol}^{-1}\right)$, in agreement with the fact that both conformations are observed in the solid state. 

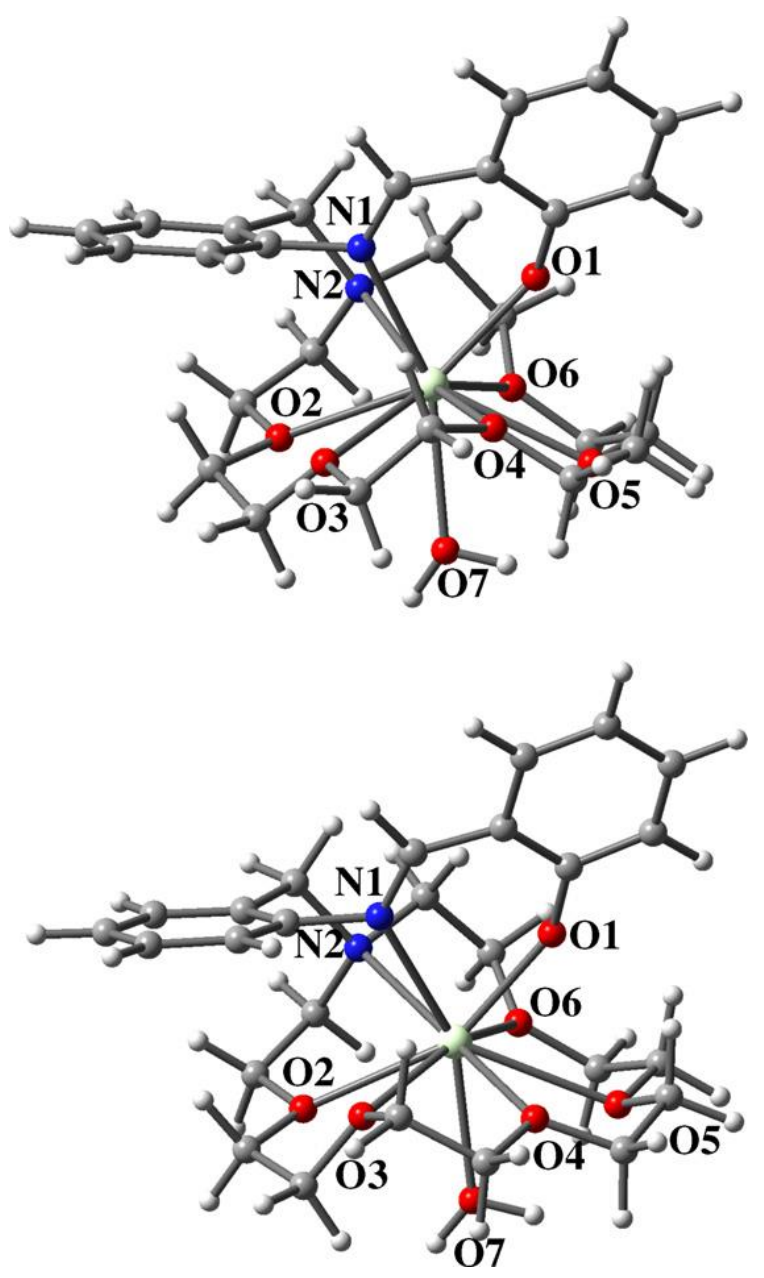

Fig. 2. Calculated structures for the $\left[\operatorname{Pr}\left(\mathrm{L}^{4}\right)\left(\mathrm{H}_{2} \mathrm{O}\right)\right]^{2+}$ system as optimised in vacuo at the $\mathrm{HF} / 3-21 \mathrm{G}^{*}$ level (top: conformation $\mathbf{A}$; bottom: conformation $\mathbf{B})$.

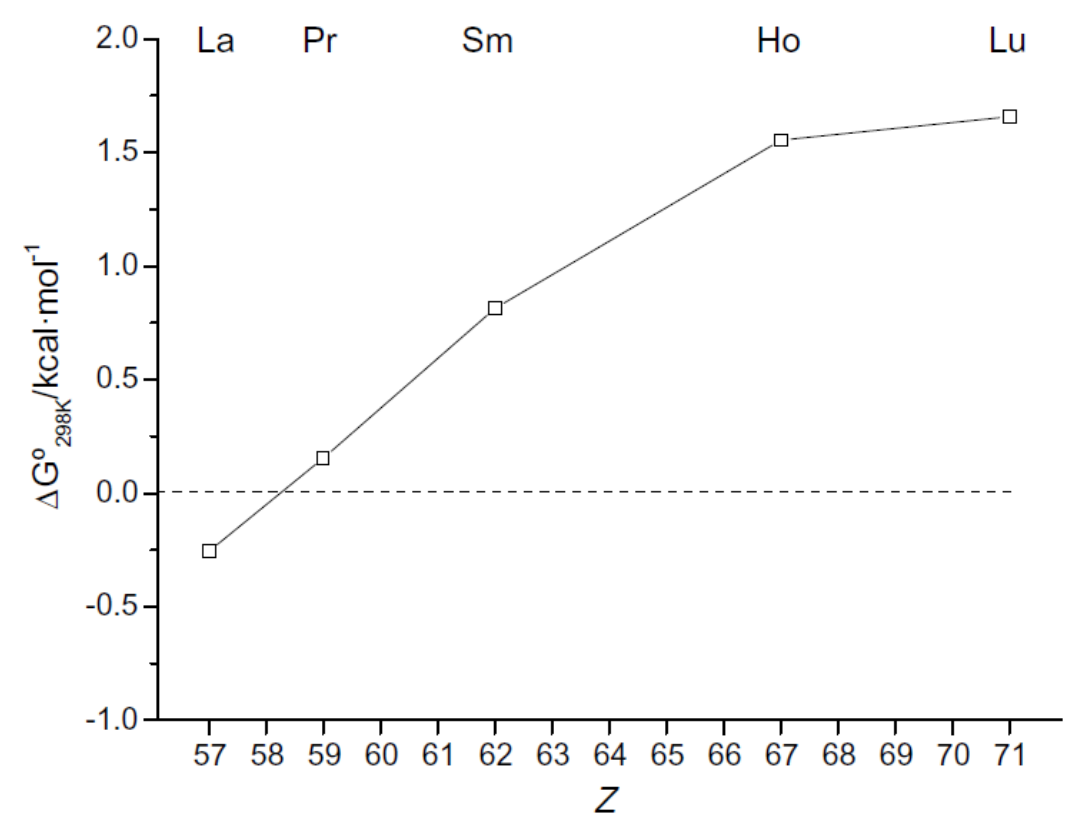

Fig. 3. In vacuo relative free energy of the $\mathbf{B}$ conformation $(\Delta \mathrm{G} 298 \mathrm{~K} \circ=\mathrm{GB} \circ-\mathrm{GA} \circ)$ in $\left[\operatorname{Ln}\left(\mathrm{L}^{4}\right)\left(\mathrm{H}_{2} \mathrm{O}\right)\right]^{2+}$ complexes. 
On the other hand, the calculated structures of the $\left[\mathrm{Ln}\left(\mathrm{L}^{4}\right)\left(\mathrm{H}_{2} \mathrm{O}\right)\right]^{2+}$ systems (A conformation) show that, with the exception of $\mathrm{Ln}-\mathrm{O}(5)$, the calculated Ln-donor bond lengths decrease along the lanthanide series (Table 2, Fig. 4), as usually observed for $\mathrm{Ln}(\mathrm{III})$ complexes. However, the $\mathrm{Ln}-\mathrm{O}(5)$ distance decreases from $\mathrm{La}$ $(2.741 \AA)$ to Sm $(2.697 \AA)$, but then increases in the Ho (2.712 $⿱$ ) and Lu (2.801 $\AA$ ) complexes (Fig. 4). A similar situation is found for conformation $\mathbf{B}$, in which the $\mathrm{Lu}-\mathrm{O}(5)$ distance amounts to $2.935 \AA$ (Table 2). Although these results should be taken with care, since no geometry optimizations have been attempted for other conformations of the macrocyclic receptor in the complexes (the $\mathbf{A}$ and $\mathbf{B}$ conformations observed in the X-ray crystal structure of the $\operatorname{Pr}(\mathrm{III})$ complex were used as input geometries), the lengthening of the Ln$\mathrm{O}(5)$ distance at the end of the series suggests that the macrocyclic cavity size of $\mathbf{L}^{4}$ provides the best fit with the lightest Ln(III) ions along the lanthanide series.

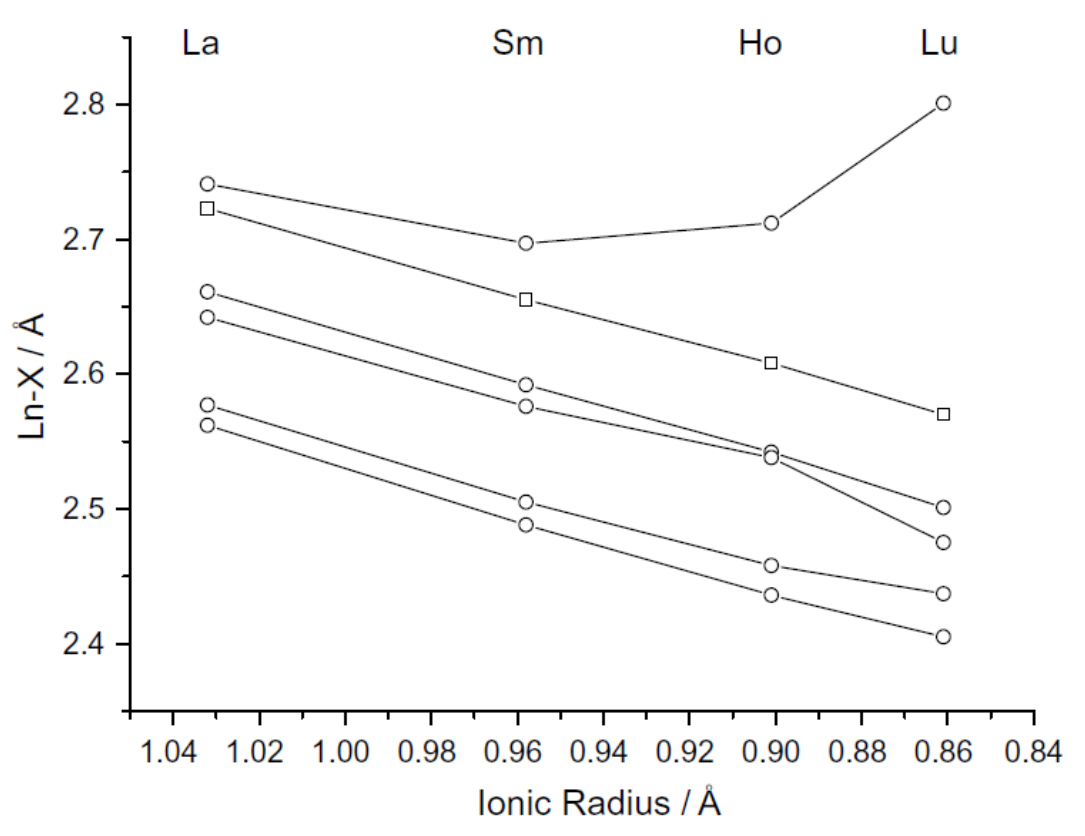

Fig. 4. $\mathrm{Ln}-\mathrm{O}_{\mathrm{C}}(-\circ-)$ and $\mathrm{Ln}-\mathrm{N}_{\mathbf{A}}(-\square-)$ bond distances calculated at the $\mathrm{HF} / 3-21 \mathrm{G}^{*}$ computational level for the $\left[\mathrm{Ln}\left(\mathrm{L}^{4}\right)\left(\mathrm{H}_{2} \mathrm{O}\right)\right]^{2+}$ complexes showing conformation $\mathbf{A}\left[\mathrm{N}_{\mathrm{A}}=\right.$ amine nitrogen atoms; $\mathrm{O}_{\mathrm{C}}=$ crown ether oxygen atoms $]$.

\section{Concluding remarks}

The mono-armed azacrown $N$-(2-salicylaldiminatobenzyl)-1-aza-18-crown-6 $\left(\mathbf{L}^{4}\right)$ forms complexes of formula $\left[\mathrm{Ln}\left(\mathrm{L}^{4}\right)\left(\mathrm{H}_{2} \mathrm{O}\right)\right]\left(\mathrm{ClO}_{4}\right)_{2} \cdot x$ solv with lanthanides from $\mathrm{La}$ to $\mathrm{Tb}$, excluding $\mathrm{Pm}$. The solid state structures of the $\mathrm{Pr}(\mathrm{III})$ and $\mathrm{Sm}$ (III) complexes, as well as theoretical calculations performed at the HF level indicate that the $\left[\mathrm{Ln}\left(\mathrm{L}^{4}\right)\left(\mathrm{H}_{2} \mathrm{O}\right)\right]^{2+}$ complexes adopt at least two different conformations along the lanthanide series. Moreover, calculated relative free energies of the two isomers along the lanthanide series are in agreement with the structures observed in the solid state. These results suggest that the energetics of these complexes can be appropriately calculated at the HF level. It is well known that the conformation adopted by a macrocyclic ligand in $\mathrm{Ln}$ (III) complexes can affect drastically some properties such as the exchange rate of inner-sphere water molecules [29]. Thus, the prediction of the structure of lanthanide complexes by using theoretical methods is important to help on the design of systems with the desired properties.

A comparison of the coordinative properties of the monobracchial lariat ether $\mathbf{L}^{4}$ with those of the bibracchial receptor $\mathbf{L}^{1}$ shows that removing a pendant arm results in a lower encapsulating capability of the 
ligand, which allows additional ligands such as water molecules to enter the inner coordination sphere of the $\mathrm{Ln}$ (III) ion in the complexes of $\mathbf{L}^{4}$, a condition required for the application of $\mathbf{L n}(\mathrm{III})$ complexes as contrast agents in MRI [1]. We are currently investigating structural modifications in the ligand backbone to improve the solubility of the complexes in aqueous media.

\section{Acknowledgements}

The authors thank the Ministerio de Educación y Ciencia and FEDER for financial support (Grant CTQ200607875), and Centro de Supercomputación of Galicia (CESGA) for providing the computer facilities.

\section{Supplementary data}

CCDC 666283 and 666284 contain the supplementary crystallographic data for crystal structure of 3 and 5. These data can be obtained free of charge via http://www.ccdc.cam.ac.uk/conts/retrieving.html, or from the Cambridge Crystallographic Data Centre, 12 Union Road, Cambridge, CB2 1EZ, UK; fax: (+44) 1223-336033 or e-mail: deposit@ccdc.cam.ac.uk. Supplementary data associated with this article can be found, in the online version, at doi:10.1016/j.poly.2008.01.004.

\section{References}

[1] (a) R.R. Edelman, M.B. Zlatkin, J.R. Hesselink (Eds.), Clinical Magnetic Resonance Imaging, 2nd ed., vol. 1, W.B. Saunders Company, Philadelphia, 1996 (Chapter 5); (b) P. Caravan, J.J. Ellinson, T.J. McMurry, R.B. Lauffer, Chem. Rev. 99 (1999) 2293; (c) A.E. Merbach, É . Tóth (Eds.), The Chemistry of Contrast Agents in Medical Magnetic Resonance Imaging, Wiley, New York, 2001.

[2] (a) T.C. Bruice, A. Tsubouchi, R.O. Dempcy, L.P. Olson, J. Am. Chem. Soc. 118 (1996) 9867; (b) P. Hurst, B.K. Takasaki, J. Chin, J. Am. Chem. Soc. 118 (1996) 9982.

[3] I. Hemmilä, T. Stahlberg, P. Mottram, Bioanalytical Applications of Labelling Technologies, Wallac Oy, Turku, Finland, 1994.

[4] D. Parker, Coord. Chem. Rev. 205 (2000) 109.

[5] (a) G.L. De Nardo, G.R. Mirik, L.A. Kroger, R.T. O’Donnel, C.F. Meares, S.L. De Nardo, J. Nucl. Med. 37 (1996) 451; (b) M.J. Heeg, S.S. Jurisson, Acc. Chem. Res. 32 (1999) 1053.

[6] (a) R. Saez-Puche, P. Caro (Eds.), Rare Earths, Editorial Complutense, Madrid, 1998;

(b) D. Parker, R.S. Dickins, H. Puschmann, C. Crossland, J.A.K. Howard, Chem. Rev. 102 (2002) 1977.

[7] Y. Liu, B.-H. Han, Y.-M. Li, R.-T. Chen, M. Ouchi, Y. Inoue, J. Chem. Phys. 100 (1996) 17361.

[8] G.W. Gokel, S.H. Korzeniowski, Macrocyclic Polyether Synthesis, Springer, Berlin, 1982.

[9] Y. Nakatsuji, T. Nakamura, M. Yometani, H. Yuya, M. Okahara, J. Am. Chem. Soc. 110 (1988) 531.

[10] C. Platas, F. Avecilla, A. de Blas, T. Rodríguez-Blas, R. Bastida, A. Macías, A. Rodríguez, H. Adams, J. Chem. Soc., Dalton Trans. (2001) 1699. 
[11] M. González-Lorenzo, C. Platas-Iglesias, F. Avecilla, C.F.G.C. Geraldes, D. Imbert, J.-C.G. Bünzli, A. de Blas, T. Rodríguez-Blas, Inorg. Chem. 42 (2003) 6946.

[12] M. González-Lorenzo, C. Platas-Iglesias, F. Avecilla, S. Faulkner, S.J. Pope, A. de Blas, T. RodríguezBlas, Inorg. Chem. 44 (2005) 4254.

[13] W.C. Wolsey, J. Chem. Educ. 50 (1973) A335.

[14] SADABS Area-Detector Absorption Correction. Siemens Industrial Automation Inc., Madison, WI, 1996.

[15] G.M. Sheldrick, SHELX97 [Includes SHELXS97, SHELXL97, CIFTAB] - Programs for Crystal Structure Analysis (Release 97-2), Institüt für Anorganische Chemie der Universität, Tammanstrasse, Göttingen, Germany, 1998.

[16] L.J. Farrugia, WINGX MS-Windows system of programs for solving, refining and analysing single crystal X-ray diffraction data for small molecules, J. Appl. Crystallogr. 32 (1999) 837.

[17] P.T. Beurskens, G. Beurskens, R. de Gelder, S. Garcia-Granda, R.O. Gould, R. Israel, J.M.M. Smits, DIRDIF99 Program System, Crystallography Laboratory, University of Nijmegen, The Netherlands, 1999.

[18] M. Dolg, H. Stoll, A. Savin, H. Preuss, Theor. Chim. Acta 75 (1989) 173.

[19] M.J. Frisch, G.W. Trucks, H.B. Schlegel, G.E. Scuseria, M.A. Robb, J.R. Cheeseman, V.G. Zakrzewski, J.A. Montgomery Jr, R.E. Stratmann, J.C. Burant, S. Dapprich, J.M. Millam, A.D. Daniels, K.N. Kudin, M.C. Strain, O. Farkas, J. Tomasi, V. Barone, M. Cossi, R. Cammi, B. Mennucci, C. Pomelli, C. Adamo, S. Clifford, J. Ochterski, G.A. Petersson, P.Y. Ayala, K. Morokuma, Q. Cui, D.K. Malick, A.D. Rabuck, K. Raghavachari, J.B. Foresman, J. Cioslowski, J.V. Ortiz, A.G. Baboul, B.B. Stefanov, G. Liashenko, A. Liu, P. Piskorz, I. Komaromi, R. Gomperts, R.L. Martin, D.J. Fox, T. Keith, M.A. Al-Laham, C.Y. Peng, A. Nanayakkara, M. Challacombe, P.M.W. Gill, B. Johnson, W. Chen, M.W. Wong, J.L. Andres, C. Gonzalez, M. Head-Gordon, E.S. Replogle, J.A. Pople, GAUSSIAN 98, Revision A.11, Gaussian Inc., Pittsburgh, PA, 1998.

[20] K. Nakamoto, Infrared and Raman Spectra of Inorganic and Coordination Compounds, 5th ed., John Wiley, New York, Chichester, Brisbane and Toronto, 1997.

[21] F. Nicolo, D. Plancharel, G. Chapuis, J.-C.G. Bünzli, Inorg. Chem. 27 (1988) 3518.

[22] U. Cosentino, A. Villa, D. Pitea, G. Moro, V. Barone, J. Phys. Chem. B 104 (2000) 8001.

[23] R.O. Freire, G.B. Rocha, A.M. Simas, J. Mol. Model. 12 (2006) 373.

[24] U. Cosentino, A. Villa, D. Pitea, G. Moro, V. Barone, A. Maiocchi, J. Am. Chem. Soc. 124 (2002) 4901.

[25] N. Quali, B. Bocquet, S. Rigault, P.-Y. Morgantini, J. Weber, C. Piguet, Inorg. Chem. 41 (2002) 1436.

[26] M.delC. Fernández-Fernández, R. Bastida, A. Macías, P. Pérez-Lourido, C. Platas-Iglesias, L. Valencia, Inorg. Chem. 45 (2006) 4484.

[27] (a) C. Platas-Iglesias, M. Mato-Iglesias, K. Djanashvili, R.N. Muller, L. Vander Elst, J.A. Peters, A. De Blas, T. Rodríguez-Blas, Chem. Eur. J. 10 (2004) 3579; (b) M. Mato-Iglesias, C. Platas-Iglesias, K. Djanashvili, J.A. Peters, E. Tó th, E. Balogh, R.N. Muller, L. Vander Elst, A. De Blas, T. Rodríguez-Blas, 
Chem. Commun. (2005) 4729; (c) M. Mato-Iglesias, E. Balogh, C. Platas-Iglesias, E. Tóth, A. De Blas, T. Rodríguez-Blas, Dalton Trans. (2006) 5404.

[28] (a) M.R. Willcott, R.E. Lenkinski, R.E. Davis, J. Am. Chem. Soc. 94 (1972) 1742; (b) R.E. Davis, M.R. Willcott, J. Am. Chem. Soc. 94 (1972) 1744.

[29] (a) M. Woods, S. Aime, M. Botta, J.A.K. Howard, J.M. Moloney, M. Navet, D. Parker, M. Port, O. Rousseaux, J. Am. Chem. Soc. 122 (2000) 9781; (b) M. Woods, Z. Kovacs, S. Zhang, A.D. Sherry, Angew. Chem., Int. Ed. 42 (2003) 5889; (c) F.A. Dunnand, S. Aime, A.E. Merbach, J. Am. Chem. Soc. 122 (2000) 1506. 